\title{
Social Media-Innovation: The Case of \\ Indigenous Tweets
}

Niamh Ní Bhroin

Department of Media and Communication, University of Oslo

n.n.bhroin@media.uio.no

\section{ABSTRACT}

Twitter presents new opportunities for individual communication. Consequently, it may be a relevant arena in which to address the social need of minority language maintenance. The Indigenous Tweets website presents a directory of minority language users on Twitter (www.indigenoustweets.com). It aims to create new opportunities to use these languages, thus to address a social need through media innovation. In this article, I draw on a theoretical framework from Media Innovation and Social Innovation Studies, to delineate the concept of Social Media-Innovation. I propose three distinguishing attributes. Firstly, users of these innovations must consider them relevant to address identified social needs. Secondly, the communication capabilities they present must support addressing these needs. Thirdly, they should facilitate mediated interaction that enhances society's capacity to act. Having delineated the concept I explore how its attributes are manifest in practice with reference to the case of Indigenous Tweets. I find that the relevance of Indigenous Tweets is negotiated with regard to culturally specific needs in different social contexts. The development and use of its communication capabilities are supported by incremental experimentation and learning. Furthermore, while it facilitates mediated interactions that are designed to enhance society's capacity to act, these occur in a hybrid media context and are influenced by the range of agents involved This article contributes to studies of Media Innovations by delineating the concept of Social Media-Innovation according to three central attributes. It also analyses how these are manifest in practice with reference to the case of Indigenous Tweets.

\section{KEYWORDS:}

Social Media-Innovation; Communication Capabilities; Mediated Interaction; Minority Languages; Indigenous Tweets

The Journal of Media Innovations 2.1 (2015), 89-106.

http://www.journals.uio.no/index.php/TJMI

(c) Niamh Ní Bhroin 2015. 
Traditional mass media services have produced limited content in minority languages (cf. Jones, 2013). Social Media present new opportunities for networked communication between individuals in such languages. Amongst these services, Twitter is distinct because it has largely been appropriated for open, or public, communication. It presents opportunities for 'microblogging', allowing users to post short messages, 140 characters in length, to networks of 'followers' (cf. Marwick and boyd, 2011). Consequently, open interaction on the Twitter platform may enhance the visibility of communication in minority languages.

The potential for individual communication in Social Media presents new possibilities to address the social challenge of minority language maintenance (cf. Jones and Uribe-Jongbloed, 2013; Kelly-Holmes, 2014; Pietikäinen and Kelly-Holmes, 2011). Paradoxically, it is acknowledged that unequal access to digital technologies can reinforce the imbalances inherent in existing power structures (Alia, 2009; Demeurt, 2014). Consequently, in this article, I aim to contribute a nuanced understanding of how Social Media can be used to address social needs. I focus specifically on the challenge of minority language maintenance.
I propose Social Media-Innovation as a concept to analyse innovations in media that aim to address social needs. I focus on how the central attributes of this concept are manifest in the process of innovation that relates to Indigenous Tweets (www.indigenoustweets.com). Indigenous Tweets presents a directory of minority and indigenous language users on Twitter. It was created to facilitate interaction between these users and to encourage them to tweet more (Scannell, 2013). It therefore aims to address a social need. It is theoretically a social innovation because it also supports the development of new relationships, and enhances society's capacity to act (Moulaert, MacCallum, Mehmood \& Hamdouch, 2013; Mulgan, 2012).

At the same time, Indigenous Tweets relies on and constitutes media innovation. It uses a web crawler to search the Twitter platform and identify instances where certain languages are used. It catalogues language-users in lists which hyperlink to their Twitter profiles. It presents these lists in a leader-board format according to who tweets most often, to the highest percentage, or most recently. It currently tracks 157 languages, and lists the top 500 tweeters in each (Scannell, 2014a).

Importantly, the concept of Social Media-Innovation does not relate exclusively to 'Social Media'. Other broadly recognisable examples might in- clude the development of participatory community radio (Day, 2008), collaborations to generate localised content in Wikipedia (Demeurt, 2014; Graham and Hogan, 2014), or practices of digital humanitarianism such as the use of Ushahidi to generate crisis information during natural disasters (Burns, 2014). I argue that delineating the central attributes of these processes supports the production of new insights into how media can be used to address social challenges. I therefore address the following research questions:

What attributes characterise Social MediaInnovation?

How are these attributes manifest in the process of innovation that relates to Indigenous Tweets?

The discussion is based on an analysis of the design and use of Indigenous Tweets during an 18-month ethnographically-inspired observational study. This involved twelve Irish- and ten Northern Sámilanguage users and an analysis of the tool itself (Scannell, 2007; Scannell, 2013; Scannell, 2014a; Scannell, 2014b). I explored interactions involving the tool in Twitter. I also conducted an in-depth content and discourse analysis of six weeks of in- 
teractions to enable a closer investigation of the participants' practices. These findings formed the basis for qualitative interviews where the design and use of Indigenous Tweets were discussed.

This article makes two contributions to the field of Media Innovation Studies. It establishes and delineates the concept of Social Media-Innovation with reference to three central attributes. It also analyses how these attributes are manifest in the case of Indigenous Tweets. Section One outlines the article's theoretical framework and delineates the category of Social Media-Innovation. Section Two presents a brief contextual note about the need to create new opportunities to use the Irish and Northern Sámi languages. Section Three discusses how Indigenous Tweets is an example of Social Media-Innovation with reference to its delineating attributes. Section Four presents the concluding remarks.

\section{SECTION ONE: SOCIAL MEDIA-INNOVATION}

As a concept, Social Media-Innovation refers to innovations in media that aim to address social needs. It is a tool to explore how constellations of agents interact to solve social problems within and across media platforms. These interactions involve the design, interpretation and appropriation of certain communication capabilities. The concept is theoretically rooted in Media Innovation Studies (Storsul and Krumsvik, 2013), while at the same time informed by theories that relate to Social Innovation (Moulaert et al., 2013; Mulgan, 2012).

To date, studies of media innovations have largely focused on changing aspects of the established journalism and audio-visual industries (cf. Storsul and Krumsvik, 2013; Westlund and Lewis, 2014). In spite of this, new practices in media, in particular but not limited to Social Media, include innovative activities by non-traditional media actors. Bruns (2014) argues that because media increasingly both drive and reflect social change, media innovations can be considered societal innovations. He demonstrates that individuals acting beyond organisational boundaries, for example in Twitter, can engage in practices of 'produsage', blurring the roles of producers and consumers to report on natural disasters or other catastrophes
(Bruns, 2012). He argues that these practices cumulate as societal innovations, whether or not they positively impact the status quo (Bruns, 2014, p 14). I argue that Social Media-Innovations, such as Indigenous Tweets, participatory community radio (cf. Day, 2008), localising content in Wikipedia (cf. Demeurt, 2014; Graham and Hogan, 2014), or mediated practices of digital humanitarianism (cf. Burns, 2014), merit separate theoretical consideration precisely because they aim to address social needs.

Both social innovations and media innovations are understood as the introduction of new combinations of existing ideas, competences and resources to a socioeconomic system (Fagerberg 2005; Mulgan 2012; Shtern, Paré, Ross \& Dick, 2013; Storsul and Krumsvik, 2013). Drawing on Frances and Bessant's (2005) four Ps of innovation, Storsul and Krumsvik (2013) point out that Media Innovation can include product, process, position and paradigm innovation. They also extend the potential for media innovations to focus on social objectives, with reference to the author's analysis of users' motivations for participating in practices of social innovation (Ní Bhroin, 2013).

Three essential attributes distinguish Social Innovation from other kinds of innovations according to the relevant literature. They must aim to solve an 
identified social need. They require the application of a range of skills or capabilities. They also bring about new relationships or collaborations that enhance society's capacity to act (Dawson, Daniel \& Farmer, 2010; Moulaert et al., 2013; Mulgan 2012). These attributes all apply to Indigenous Tweets. It is therefore a social innovation. However, Indigenous Tweets is also a media innovation. Consequently, it presents an interesting, but by no means unique case, where attributes of social innovations and media innovations intersect.

Recent developments in the field of Media Innovation Studies analyse their distinct socio-technical genesis. Perspectives from Science and Technology Studies ('STS') have been used to assess this (cf. Colbjørnsen, 2015; Westlund and Lewis, 2014). ${ }^{1}$ These perspectives focus on the roles of both actors and actants as agents of change. The concept of an actant is derived from literary studies and used in Actor-Network Theory ('ANT') to refer to a non-human agent (Latour, 2005). A magic wand is a typical example of a literary actant. It is a nonhuman agent that causes a particular outcome (Latour, 2005, p. 54-55). Within studies of the Social

1 The Journal of Media Innovations has also recently been established to explore media innovations and act as a point of focus for theoretical research in the field.
Construction of Technology ('SCOT') the concept is considered controversial because it draws attention away from the fact that all technology is ultimately socially constructed and inscribed with certain values. For example, a magic wand can cause 'good' or 'evil' outcomes depending on how it is inscribed with power by its user, and on how the outcomes it causes are socially understood (cf. Oudshoorn and Pinch, 2003).

Despite the controversy, the concept of 'actant' serves as a useful heuristic to highlight the presence and causality of non-human agents in sociotechnical media innovation. Examples of technological actants include algorithms, databases and content management systems that influence and constrain social interaction in mediated spaces (cf. Westlund and Lewis, 2014). Inspired by perspectives relating to SCOT, the concepts of actors and actants are also useful to explore how a range of values and interests influences processes of Social Media-Innovation.

Earlier work in the fields of media and cultural studies provides additional concepts to explore how the relevance of Social Media-Innovations, with regard to addressing social needs, is negotiated. Concepts such as Mansell's (1996) axial principles of 'capabilities' and 'design' are useful to overcome what Oudshoorn and Pinch (2003) have referred to as 'the artificial divide between design and use'. Furthermore, Feenberg's (2005) 'instrumentalization theory' indicates the processes by which technologies are designed and used and how these relate to an interpretation of their suitability to address specific purposes. Moreover, Feenberg's (2012) argument that the Internet is a technology in flux, for which innovative uses continue to be derived, highlights the dynamic foundations from which some processes of Social Media-Innovation may emerge.

The concept of 'domestication', originally used by Silverstone and Hirsch (1992) to analyse the appropriation of technology in the home, and further extended by Lie and Sørensen (1996) to broader organisational and social contexts, is also useful when discussing Social Media-Innovations. This is because it facilitates the inclusion of cultural, societal and economic factors in an analysis of the appropriation of technology (Sørensen, 2013). It therefore helps to explore the factors that influence how the capabilities of a Social Media-Innovation are designed and used, and how they are considered relevant (Sørensen, 2013, p. 15). In this regard, Lievrouw (2012, p. viii) has pointed out that because the Internet is designed for survival, redundancy and openness, it resists the closure and stabilisation that have marked interpretations of 
earlier communication technologies (see also Lievrouw and Livingstone, 2006). This resistance to closure also supports processes of Social MediaInnovation.

Combining these theoretical developments, I focus on three distinguishing attributes of social innovations to incorporate considerations about the socio-technical genesis and capabilities of media innovations. In doing so, I delineate the category of Social Media-Innovation. These media innovations should also be considered relevant by users to solve identified social needs. This relevance is determined with reference to their media-specificity. They should present social and technological communication capabilities that facilitate addressing the needs identified. They should also bring about mediated interaction, between actors and actants, which enhances society's capacity to act.

In the next section I briefly summarise how the social need to create new opportunities for minority language use is manifest in the Irish and Northern Sámi cases. I then analyse Indigenous Tweets as a Social Media-Innovation with reference to the distinguishing attributes I have identified.

\section{SECTION TWO: CONTEXT}

In both the Northern Sámi and Irish language cases, more or less formalised social movements have historically mobilised to achieve political language-related goals. These have included creating opportunities to use these languages in media (cf. Hourigan, 2004; Ijäs, 2012; Skogerbø, 2000). This influences the contexts in which Indigenous Tweets, as a Social Media-Innovation, is introduced and considered relevant.

The Northern Sámi Language Case

Northern Sámi is one of nine varieties of Sámi languages. It is unclear how many people speak it. This is partly because Sámi people live primarily in four countries, in Norway, Sweden, Finland and Russia, in an area known as Sápmi (see Figure 1). ${ }^{2}$ It is estimated that between 30,000 and 40,000 people understand a Sámi language, with the majority of these (ca. 90\%) belonging to the dominant, Northern Sámi group, and living in Norway (Mag-

2 Recent research estimates that 150,000 Sámi people live in these four countries (cf. Rasmussen and Nolan, 2011).

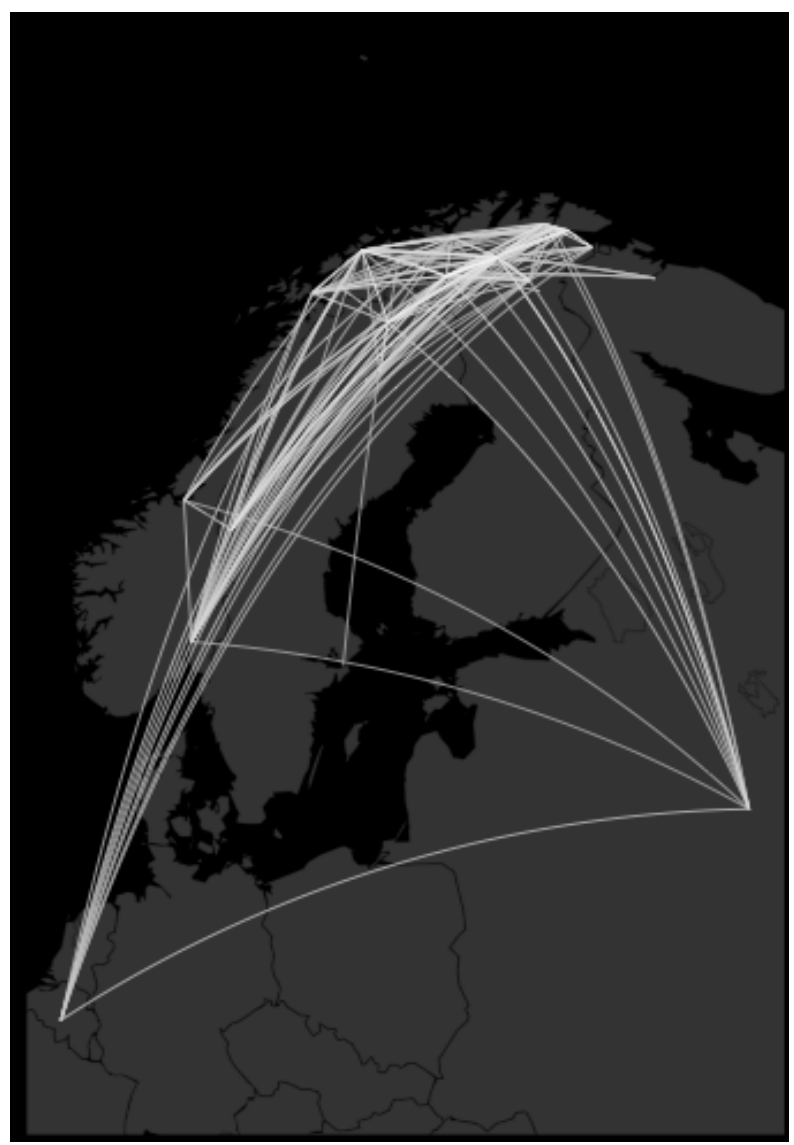

Figure 1. Source of Tweets in Northern Sámi (Source: Scannell, 2014c) The majority of Tweets originate in Sápmi, with the exception of Oslo, Brussels and Moscow. 
ga, 1997; Rasmussen and Nolan, 2011). ${ }^{3}$

Northern Sámi was historically an oral language. Religious missionaries and researchers produced the first texts in the language in the seventeenth century. Magga (2002) has argued that this contributed to a sense of inferiority amongst members of the community with regard to their ability to communicate in writing in their own language. This was compounded by a range of assimilation policies that denied education in the language between the mid-nineteenth and mid-twentieth centuries (Helander, 2005; Magga, 2014). To the present day, the precarious status of the language is manifest in the attitudes of some parents, who do not consider that their children should learn it at school (Rasmussen and Nolan, 2011).

The survival of Northern Sámi can be attributed to the mobilisation of various social movements to gain increased rights for Sámi people. While these began to take shape in the early 2oth Century, their most significant focal point was the protest against the construction of a hydroelectric dam at Alta in Northern Norway between 1979 and 1981. This cultural and environmental protest brought a renewed

3 For a further discussion on difficulties ascertaining numbers of speakers of minority languages, see Moore, Pietikäinen and Blommaert (2010). energy to the promotion of Sámi interests (Brantenberg, 2014; Ijäs, 2012). ${ }^{4}$

In Norway, Sámi was recognised as an official language in 1988, and the Sámi Language Act came into effect in 1992, giving the established Sámi parliament partial responsibility and power in educational matters (Weber and Horner, 2012). Administrative areas were delimited within which it was possible to use Northern Sámi to engage with official institutions (Magga, 2014). Cultural and media institutions were also established (Skogerbø, 2000). In spite of these measures opportunities to use the language in everyday contexts are still limited (Sametinget, 2012).

The Irish Language Case

Irish was the primary language spoken in Ireland until the eighteenth century. Processes of colonisation, combined with famine and emigration resulted in its declining relevance (Ó hIfearnáin, 2001 ). By 1926 , only $18 \%$ of the population of the Irish Free State could speak it (CSO, 2014). In 1921, the Anglo-Irish Treaty created the Irish Free State (which became the Republic of Ireland in 1937)

4 The dam was constructed in Alta, destroying a traditional area of land used by the Sámi and considered of international environmental value. and Northern Ireland. Both administrations implemented radically different approaches to language planning.

Irish was adopted as 'the national language' in the Irish Free State, a central tool in the construction of a unique Irish identity. It was to be preserved as a spoken language in 'Gaeltacht' areas, where it was assumed that it was the primary language of communication. National Irish-language education was introduced to increase the bilingual population. Although measures to protect the language in Gaeltacht regions have largely failed (Ó Giollagáin, Mac Donnacha, Ní Chualáin, Ní Shéaghadha \& O’Brien, 2007), educational policies have produced a large bilingual population (Cronin, 2005).

Roughly 40\%, or 1.77 million Irish people state that they have some competence in the language. However, only 94,000 or just over $2 \%$ use the language daily outside of the education system (CSO, 2011). This highlights a lack of opportunities to use the language for those who can speak or understand it (Caulfield, 2013).

In response to waning official interest, social movements were constituted to promote the rights of the language community. Hourigan (2004) outlines how these movements established pirate ra- 


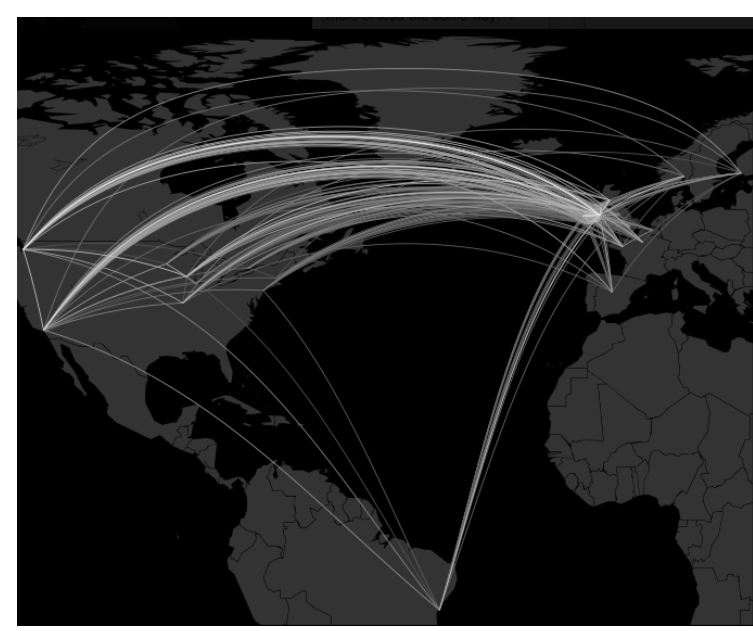

Figure 2. Source of Tweets in Irish

(Source: Scannell, 2014d)

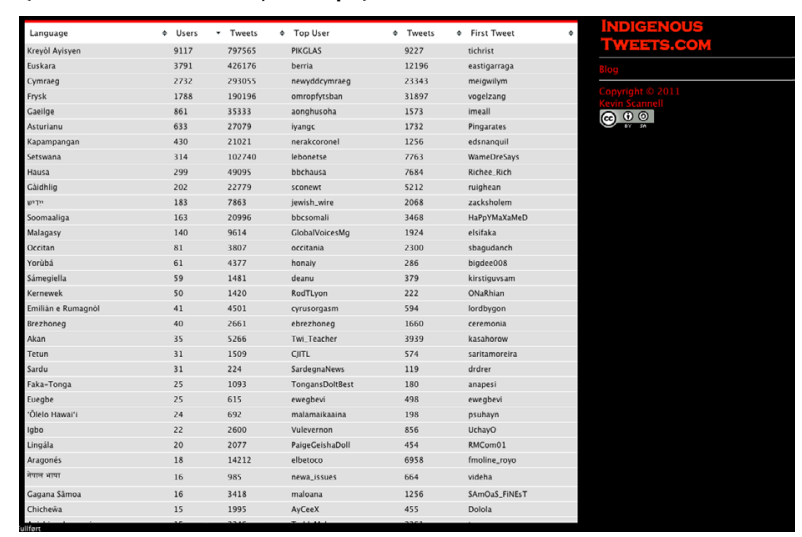

Figure 3. Indigenous Tweets Home Page

(Source: Scannell, 2014a) dio and television stations. These were ultimately formalised as public service broadcasters (Hourigan 2004; Watson 2003). These movements demonstrate the requirement for a combination of top-down and bottom-up initiatives to support language maintenance (Moriarty 2014).

By contrast, the rights of Irish language users in Northern Ireland were at best ignored until the ratification of the Good Friday Agreement of 1997, and subsequently the European Charter for Regional or Minority Languages in 2001. ${ }^{5}$ This related to a political struggle surrounding the union of the province with the United Kingdom. A frustration with the absence of civil rights, coupled with a desire to be part of an independent Irish republic led to the foundation of the terrorist organisation, the Irish Republican Army (IRA). This movement adopted the language as a symbol of nationalism. In particular it was used as, and came to symbolise, a secret mode of communication between political prisoners (Malcolm, 1997).

Furthermore, a history of significant emigration has generated a global Irish-speaking diaspora. Figure 2 shows that Tweets in Irish are sent from areas including Canada, the USA, and Brazil.

5 This charter does not apply in the Republic of Ireland because of the status of Irish as a national language.
This diaspora has limited opportunities to use the language. McGonagle (2012), for example, has explored the extent to which Irish language users living in Canada have opportunities to communicate.

The Irish language has been promoted and politicised in a variety of ways in the Republic of Ireland and Northern Ireland. It is also used by an international diaspora in a range of different multilingual locations. These present different contexts into which Indigenous Tweets is introduced and appropriated. 
SECTION THREE: DISCUSSION AND

\section{ANALYSIS}

In this section, I analyse how the delineating attributes of Social Media-Innovation that I proposed in Section Two are manifest in the process of innovation that relates to Indigenous Tweets. The discussion focuses on considerations about the relevance of Indigenous Tweets to address a social need; the communication capabilities it presents; and the mediated interactions it brings about.

The interview extracts in this section are presented in English although originally conducted either in Irish or Norwegian and Swedish. All participants are referred to by an altered first initial to protect their privacy. 'I' or 'NS' indicate the case they belong to. Kevin Scannell is referred to as 'KS'.

\section{Relevance}

Figure 3 presents the Home Page of the Indigenous Tweets tool. Its purpose is to create new opportunities for indigenous and minority language use in Twitter. It presents a directory of these languages users and aims to encourage them to tweet more (Scannell, 2013). The social need that the tool addresses is internationally relevant. However, it currently identifies 157 different languages. Each of these presents a different context where the rel- evance of the tool is negotiated.

Currently, the tool identifies 7,426 Irish-, and 136 Northern Sámi language users. ${ }^{6}$ All twelve of the participants in the Irish language case used Twitter and the Indigenous Tweets tool. In the Northern Sámi case, only six participants had Twitter accounts. Three of these used Indigenous Tweets. The lower level of engagement in this case can primarily be attributed to considerations about the extent to which other users of the Northern Sámi language can be reached via the Twitter platform (Ní Bhroin, 2015, in preparation).

The Irish Language Case:

The participants in this case were based in the Republic of Ireland (eight), in Northern Ireland (two), and included members of the Irish-language diaspora (two). Ten (of twelve) had very limited opportunities to use the language. Their limitations varied according to the different political and cultural contexts in which they were situated. These in turn influenced how they understood the relevance of the tool. Five users mentioned browsing the Irishlanguage list on Indigenous Tweets to identify people that they could include in their communi-

6 These numbers have increased from 861 and 59 respectively in May 2011. cation networks (C(I), B(I), V(I), J(I), U(I)). This underlines the relevance of the tool as a directory for them.

Kevin Scannell's primary motivation in creating Indigenous Tweets was his personal interest in using the Irish language (Scannell, 2013). In spite of this, the impetus to create the tool came from his involvement with international colleagues working to protect under-resourced languages in computermediated contexts:

KS: Ah, it was an accident, em, just... I got an email from a friend in Haiti. He said: 'Oh can you, you know, you're doing Language Identification, em. Can you gather every Tweet in Haitian Creole?'

KS: So it was just an experiment for a weekend, and I just kind of created a little programme that you know collected all the Tweets for about three weeks or a fortnight in Haitian Creole. Ahm, and the result of that was: 'Oh wow! What's that? That was easy. I should do the same thing for Irish, and then, for other languages.'

The impetus to create Indigenous Tweets was therefore socially derived and related to understandings of technological capabilities.

Residing in Saint Louis, Missouri, Scannell first 
learned Irish from books, dictionaries and novels. During the 1990s he used the language in email lists and bulletin boards but found the asynchronous nature of communication there to be unsatisfactory to support his learning needs, particularly after visiting Ireland for the first time:

KS: I started going to Ireland regularly, maybe just ten years ago. And before that, I wasn't able to say anything in the language, I just couldn't. I was fluent as a reader and writer, on the Internet, you know. I had the grammar and a large vocabulary. But when I visited, on the first visit, I was just dumb! (Laughs). Author: Ok, yeah?

KS: You know in the Gaeltacht just, eh, em I thought: 'Oh you know the language', you know, 'You can read signs and...' Yeah, but, so... so it was kind of a shock to the system. (Laughs)

Author: Yeah, yeah (Laughs)

KS: So, em, so it (Twitter) is a kind of, simulation, just eh, a natural life for the language.

Scannell's desire to create new opportunities for language use was shared by other participants. However, they experienced different challenges relating to the contexts in which they were situated. Another participant, from Northern Ireland, discussed how her discomfort using the language in public, due to its political significance, restricted her opportunities to communicate.

D(I): I think it relates to certain areas. I would be very comfortable using it (Irish) in Belfast, in a nationalist area. Not like - on the Falls Road you're ok. Everyone knows that. You wouldn't say anything about it. And in Derry, and I guess if you're going to be blunt about it you would feel comfortable using it in nationalist areas and you wouldn't in others. You wouldn't see me speaking Irish on the Shankill Road in a million years. And I guess everyone agrees about that. There are some people who can be a bit more demanding. I was in South Belfast a couple of months ago and I was speaking to a friend in Irish. And I noticed - we were maybe on Botanic Road and that's a nice area you know, like the University area, so it shouldn't be any problem. There shouldn't be any difficulty with it, but I still felt strange about it. He was comfortable, but I was a bit paranoid about it I suppose.

This reveals that users of Indigenous Tweets within the same language case experience challenges regarding language use in different ways. This influenced how they regarded the relevance of the tool.
The Northern Sámi Case:

A much lower number of Northern Sámi users have Twitter accounts. In spite of this, the participants in this study used Indigenous Tweets (B(NS), T(NS), $\mathrm{N}(\mathrm{MS})$ ). One participant discussed her ambivalent relationship to her Twitter account:

$\mathrm{B}(\mathrm{NS})$ : In reality I have a kind of ambivalent relationship to that Twitter account. Because I actually don't want to Tweet, but I think it is important to, to Tweet anyway.

Author: Ok - and why?

B(NS): ... It's good to retweet the things I think are important and that I think others should be aware of, so I tweet that. And it's also a good way to cite yoiks, yoiks, like these kinds of rhythms that are very beautiful, poetic with beautiful words, and maybe more people see them.?

Other participants, located in Norway and Sweden, wanted to make elements of the Sámi culture and language visible. Their different locations influenced how they interacted. One communicated largely in a Norwegian dialect as she wanted to in-

7 Yoiking is a traditional form of Sámi vocal music. For a detailed description see Graff (2014) 
form Norwegians about Sámi culture (T(NS)). Others, based in Sweden, were concerned about the lack of visibility of the language in their local environments, and wanted to make it visible on Twitter (N(NS) and J(NS)). In spite of this, the small number of other language users interacting in Twitter meant that the participants didn't think it was relevant as a space in which to expand their language networks (Ní Bhroin 2015, in preparation). This in turn influenced how they regarded the relevance of Indigenous Tweets.

The Northern Sámi participants revealed that they used Twitter to make their language visible, while the Irish language participants were looking for opportunities to extend their networks and use the language in synchronous communication contexts. The relevance of Indigenous Tweets was therefore negotiated in different ways in each case. Furthermore, processes of domestication varied within cases according to the different cultural contexts in which language-users were situated. This indicates that the relevance of Social MediaInnovations is negotiated with regard to culturally specific needs in different social contexts.

Communication Capabilities

Indigenous Tweets does not present a radically new suite of communication capabilities. It em- ploys a web crawler, 'Crúbadán', to gather statistical information about the users of relevan languages. It presents this information as a listed directory. Users can browse the directory to hyperlink to others that Tweet in their language. As a result, Indigenous Tweets is a complementary tool, relying on the communication capabilities of both Twitter and Crúbadán. It applies existing knowledge to design incrementally new communication capabilities.

'Crúbadán' was originally designed by Scannell in 1999 to support the development of an Irishlanguage spell checker. It downloaded websites and processed them to enhance the spell-checking database. It statistically identified languages using character trigrams, a process known as natural language identification. Recognising that Crúbadán could support other lesser-resourced languages on the Internet, Scannell worked with local language collaborators to train the crawler to recognise a further 144 languages by 2004 (Scannell, 2007, p. 1). The incremental development and expansion of Crúbadán's capabilities is central to the design of the Indigenous Tweets tool. It is why Indigenous Tweets can recognise 157 languages.

The design and development of these tools relies on Scannell's competence as a computer scientist. It also relies on his engagement with pro- jects to support lesser-resourced languages over time. This engagement included interactions with others that helped him to train Crúbadán to recognise their languages. As discussed previously, these interactions also provided the impetus for $I n$ digenous Tweets. This case therefore demonstrates that communication capabilities have both social and technological elements and are incrementally developed.

Figure 3 presents the simple design of the $I n-$ digenous Tweets Home Page. The site represents a domestication of Twitter's communication capabilities based on Scannell's personal design, and supported by the Crúbadán crawler. For example, the directory can be searched, according to username, total and percentage, because of Scannell's desire to interact with people who communicate almost exclusively in Irish. Furthermore, the interface deliberately facilitates easy translation into any language. Only thirteen simple phrases require translation (Scannell, 2014a).

The communication capabilities of Indigenous Tweets are also constrained by those presented by Twitter. The directory only lists the top 500 Tweeters in each language. This arises from Twitter's implementation of a 500-user limit on its list function. Furthermore, Crúbadán can only access and generate statistics that relate to accounts that operate 
openly on the Twitter platform. Accounts that implement 'privacy settings' cannot be accessed. Even if users allow Scannell, as an individual, to access their accounts, the crawler cannot process their data because of their appropriation of the more restrictive capabilities of the Twitter platform:

KS: Its just a question of privacy really, you know, everything on Twitter, em, its public, and, ... I can't, just for technological reasons em, follow those accounts and put the statistics on Indigenous Tweets

KS: ... Yeah, so just, eh, you know, it is a computer programme that collects the statistics. ... I can read private accounts, but the programme can't pick them up.

The case of Indigenous Tweets therefore demonstrates that the communication capabilities of Social Media-Innovations are constrained by the capabilities of the range of actors and actants they involve.

Capabilities become relevant through interpretation and use. One participant (C(I) discussed how he gradually appropriated different technologies to use the Irish language online in a blog post. He had used email lists, message boards, and a personal website. He currently mostly blogs and uses Twitter. He discusses the different communication ca- pabilities of these forums, comparing Twitter to a conversation in a pub, albeit one where the Irish language can be used more consistently. He enjoys the linguistic challenge of issuing short Tweets. The 140-character Tweet constraint in turn represents an incremental innovation influenced by the original constraints of SMS messages. In this blog post $\mathrm{C}(\mathrm{I})$ links to the Irish page on the Indigenous Tweets site, referring to it as the 'Cúinne Gaeilge' or Irish-language corner, on Twitter. This blog post demonstrates how communication capabilities evolve over time and are interpreted based on previous experiences.

Users in the Northern Sámi case have also been domesticating incremental developments in communication capabilities to communicate in their language. One site that was particularly relevant in this regard was Samenet. This was a project established by the Swedish Sámi Association in cooperation with the Sámi Education Centre in Jokkmokk in 1997. Some of the participants in this study used it to keep up to date with issues in Sápmi and to communicate in Northern Sámi. The platform decreased in relevance and was eventually removed because participants had migrated to Facebook. One of the participants discussed this:

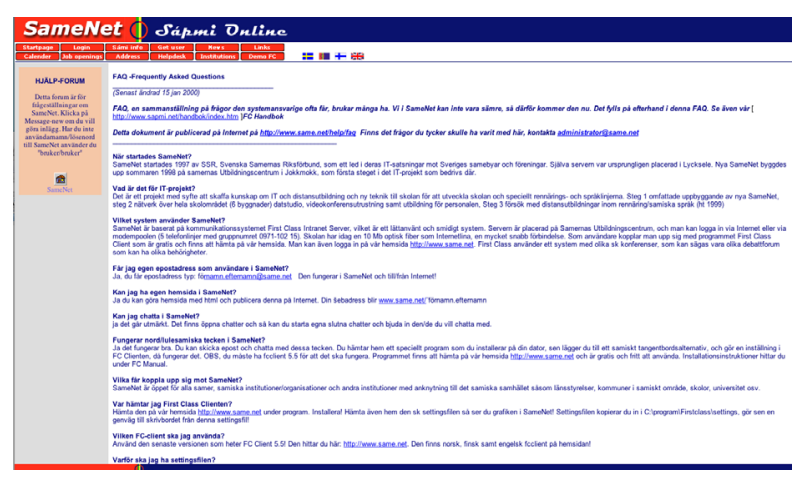

Figure 4. Samenet (Source: Internet Archive, 2014) 
K(NS): We had a, before Facebook came, and before other Social Media, there was a kind of Internet programme, that was called Samenet. There were 3,000 members there at its highest. There were, it was a kind of large social network, where people posted, and it was really popular, and that was before, I believe it was before any of the other Social Media came. It was like our own Sámi Facebook (Laughs) for its time.

Author: Yes. And what happened with that?

K(NS): Em, when the larger Social Media came it was used less and less. And, it was a project that, I don't know who had financed it. It was on the Swedish side. But it was quite large and they had their own servers and all of that strange stuff. ...

Author: So it's most likely that those members are using Facebook now?

K(NS): Mmhm. And I used a lot of other Social Media before Facebook, Link and Nettby, and these Norwegian ones, Lunarstorm in Sweden. But now Facebook has become like a gathering point for everyone.

This extract indicates that the interpretation and domestication of communication capabilities evolve over time. It also points to the importance of Facebook (rather than Twitter) as a gathering point for users of the Northern Sámi language.
The Indigenous Tweets tool is inscribed with and signifies communication capabilities that are aimed at creating new opportunities for minority language use. The interpretation of these capabilities is grounded in evolving understandings of previous capabilities and their domestication for minority language use.

Mediated Interaction

By presenting Twitter users in a directory format, Indigenous Tweets increases the visibility of minority language-users and enhances their capacity to interact Two other aspects of Indigenous Tweets directly influence the participants' capacity to act. These relate to the presentation of the directory in a 'leader-board' format, and the extent to which the innovation occurs in a hybrid media context.

The Leader-Board

As discussed above, Indigenous Tweets lists users according to those who tweet the most, and the percentage of tweets they post in a particular language. The lists for each language can be filtered and adjusted according to these categories. This 'leaderboard' presentation style echoes practices in processes of Open Innovation, where users are ranked according to the amount or nature of their contributions to a specific project (cf. vonHippel, 2005).
The participants state that this presentation style is motivational. In the Irish language case, a number of the participants discussed their 'ranking' on the list. Figure 5 shows one participant Tweeting about her ranking, showing a sense of pride in being amongst the 'leaders' in the Irish language tweeting community.

In the Northern Sámi case, there was also a sense that awareness about the tool, and its leader-board presentation style, motivated people to Tweet in this language

Author: Have you noticed by the way that there has been a large increase in the number of people using Twitter (in Northern Sámi) in the past two months?

B(NS): Oh yes, but I believe that was after that link was published, ok about Indigenous Tweets, I believe in fact that was what did it, because I think people got a bit of a, like, 'I also want to be up there.' (Laughs)

Author: Yes.

$\mathrm{B}(\mathrm{NS})$ : And I actually want to be on top of that list. (Laughs)

Author: (Laughs)

B(NS): But I am not and I need to Tweet much, much more to get there. (Laughs) But a colleague consoled me and said that I had a better percentage of Sámi language use than (Name) but even still 


$$
\mid \begin{aligned}
& \text { ar indigenous tweets tá mise ag uimhir a tri } \\
& \mathrm{a} 2 \mathrm{~S} \text { Sep }
\end{aligned}
$$

\section{(Laughs)}

Author: (Laughs)

$\mathrm{B}(\mathrm{NS})$ : It has become like that. I want to be on top.

Figure 5. J's Tweet: Translation: on indigenous tweets I am number three (Source: Twitter, 2014)

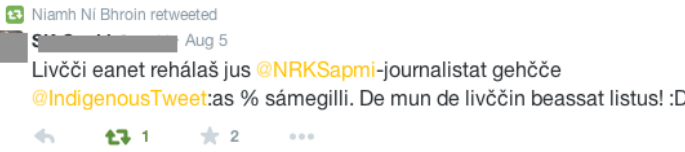

Figure 6. Northern Sámi participant discussing Indigenous Tweets (Source: Twitter, 2014)
The Tweet in Figure 6 was posted in August 2014 following the publication and distribution of an article on NRK Sápmi about Top Tweeters in Northern Sámi as presented by Indigenous Tweets (Henriksen, 2014). Here one participant (T(NS)) notes that if the journalist had filtered the list according to the percentage of language use, she would have been included among the top tweeters.

Hybrid Media Contexts

Indigenous Tweets addresses a social need by generating statistical information about users on the Twitter platform. It therefore relates to a hybrid media context. Twitter is a commercial platform. It gathers data about its users and trades this with advertisers. As such, the interests of these two primary actants are not aligned. Some concerns, with particular in regard to privacy, influence the extent to which users interact with the Social Media-Innovation process. Scannell refers to these in a blog post about creating visualisations of Tweets such as those presented in this article (Figures One and Two). These images are based on the geolocation of tweets posted on Twitter. Scannell notes that the data is aggregated and as a result individuals cannot be identified. At the same time he states that it is possible for people to disable the geolocation function through their Twitter accounts in order to protect their privacy (Scannell, 2014c). This tension between the implementation of more restrictive privacy settings and the 'open' communication capabilities of the Indigenous Tweets tool is also discussed above.

One participant used a pseudonym in Twitter because she considered it a good way to protect her privacy and to enable her to interact 'freely' with people. However, she ultimately stopped using Social Media because she felt that they were encroaching on her privacy. This participant had Tweeted a lot in Irish and was one of the 'leaders' on the Indigenous Tweets platform. However, once her account was deleted, these tweets and her ranking were no longer displayed. She discussed the potential impact of this for the Irish language community:

D(I): Actually it occurred to me the other day about Indigenous Tweets. I hope I didn't delete like five thousand Tweets in Irish and that Irish fell down the table or something like that. I saw (name) in the 'Siopa Leabhar' (a book shop). I know him to see and I met him, and he was like: 'What happened to you?' 
you know 'You're supposed to be beating me and taking first place', and I was like oh shit, well... I hope I didn't damage the Irish language when I left.

Although this participant demonstrates a sense of humour in terms of her decision not to use Twitter, her motivation relates to a serious concern about her privacy. This concern provides an important insight into the process of Social Media-Innovation as it relates to interactions between social actors and technological actants. The Indigenous Tweets tool relies on a number of compatible communication capabilities in hybrid media contexts. In spite of this, not all of the actors and actants involved have completely compatible interests. As a result, conflicts of interest can arise that influence the process of innovation. This interview extract also reveals that the alignment of interests in Social Media-Innovation processes can change over time.

\section{SECTION FOUR CONCLUDING REMARKS}

In this article I develop the concept of Social MediaInnovation according to three central attributes. I explore how these attributes are manifest in the case of Indigenous Tweets. Social Media-Innovations must be considered relevant to address identified social needs. Their communication capabilities should support addressing these needs. They should also involve mediated interaction between users and technology that enhance society's capacity to act.

I show that the relevance of Social Media-Innovations is negotiated in different contexts according to culturally specific needs. Indigenous Tweets is an international innovation that supports 157 languages. The social need to use each of these languages is manifest in different cultural contexts. I discuss how the Northern Sámi participants primarily aim to make their language visible in Twitter, while the Irish language participants want to expand their communication networks and generate new opportunities for synchronous communication. These needs influence the way in which Indigenous Tweets is considered relevant and domesticated.

As a Social Media-Innovation, Indigenous Tweets does not constitute a radical departure from the communication capabilities of the Twitter platform. Instead, it represents the application of existing knowledge to the design of incrementally new communication capabilities. It builds on the capabilities of the Twitter platform and the Crúbadán crawler. The participants' interpretations of these capabilities are grounded in understandings that have developed through their incremental appropriation and use of evolving communication technologies. The case therefore demonstrates that incremental experimentation and learning support the design and use of communication capabilities.

Finally, I discuss how two aspects of interactions with regard to Indigenous Tweets influence the participants' capacity to act. I reveal that users appropriate the 'leader-board' capability and consider it to be a motivating factor for communication. I also discuss how the hybrid context in which Indigenous Tweets operates influences the Social Media-Innovation process. This includes actants with different interests such as Twitter and Crúbadán. Although the capabilities of these actants align to support Social Media-Innovation, they are designed for different purposes. This represents a dilemma for some of the participants in the study. The case therefore indicates that Social media-Innovation is influenced by the interests of the range of agents that interact in hybrid media 
contexts.

It must be noted that the findings of this study are limited by its micro-sociological nature. Further research is required to test their relevance in the context of other processes of Social Media-Innovation. This includes other cases where the communication capabilities of Social Media platforms are used to generate new opportunities for minority language use. In spite of these limitations, in delineating the concept of Social Media-Innovation, and analysing how its key attributes are manifest in the case of Indigenous Tweets, this article makes two important contributions to the field of Media Innovation Studies.

\section{ACKNOWLEDGEMENTS:}

The Faculty of Humanities at the University of Oslo funded this research.

This research would not have been possible without the participation of Kevin Scannell (creator of Indigenous Tweets), and the research participants in the Irish and Northern Sámi language cases.

The author is also indebted to Tanja Storsul, Pia Lane and the anonymous reviewers for the comments and feedback provided.
REFERENCES

Alia, V. (2010). The New Media Nation: Indigenous Peoples and Global Communication. New York: Berghahn Books.

Bruns, A. (2012). Ad Hoc Innovation by Users of Social Networks: The Case of Twitter. ZSI Discussion Paper 16. Retrieved from https://www.zsi-at/object/ publication/2186

Bruns, A. (2014). Media Innovations, User Innovations, Societal Innovations. The Journal of Media Innovations, 1(1), 13-27.

Brantenberg, T. (2014). Politics of Belonging - The Sámi Movement. In M. A. Hauan (Ed.), Sámi Stories: Art and Identity of an Arctic People (37-56). Tromsø: Orkana Akademisk.

Burns, R. (2014). Moments of closure in the knowledge politics of digital humanitarianism. Geoforum 53, pp. 51-62.

Caulfield, J. (2013). A Social Network Analysis of Irish Language use in Social Media (Unpublished doctoral dissertation). Cardiff University: Wales. Retrieved from http://orca.cf.ac.uk/53228/1/Completed\%20 Phd\%20181113.pdf 
Colbjørnsen, T. (2015). Digital divergence: analysing strategy, interpretation and controversy in the case of the introduction of an ebook reader technology. Information, Communication \& Society, 18(1), 3247

Cronin, M. (2005). An Ghaeilge san Aois Nua/Irish in the New Century. Dublin: Cois Life Teoranta.

CSO. (2011). Information Society and Telecommunications in Households 2009-2011. Dublin: Stationery Office. Retrieved from http://www.cso.ie/en/media/ csoie/releasespublications/documents/informationtech/20 11/isth2009-2011.pdf

CSO. (2014). Table 4: Actual number and percentages of Irish speakers in Saorstát Éireann in 1911 and 1926 with corresponding particulars for the Irishspeaking and partly Irish-speaking areas in the Gaeltacht. Dublin: Stationery Office. Retrieved from http://www.cso.ie/en/media/csoie/census/census1926results/volume8/C\%201926\%20VOL\%208\%20 T3,4.pdf

Dawson, P., Daniel, L., and Farmer, J. (2010). Editorial. International Journal of Technology Management, 51(1), 1-8.

Day, R. (2008). Community Radio in Ireland: Participation and Multi-Flows of Communication. New York: Hampton Press.
Demeurt, A. (2014). Sites of struggle and possibility in cyberspace: Wikipedia and Facebook in Africa. In J. Androutsopoulos (Ed.), Mediatization and Sociolinguistic Change (pp. 487-514). Berlin: DeGruyter.

Fagerberg, J. (2005). Innovation: A Guide to the Literature. In J. Fagerberg, D. C. Mowery and R. R. Nelson (Eds.), The Oxford Handbook of Innovation (pp. 1-26). Oxford: Oxford University Press.

Feenberg, A. (2005). Critical Theory of Technology: An Overview. Tailoring Biotechnologies, 1(1), 47-67.

Feenberg, A. (2012). Introduction: Toward a Critical Theory of the Internet. In A. Feenberg and N. Friesen (Eds.), (Re)Inventing the Internet: Critical Case Studies (pp. 2-17). Rotterdam: Sense Publishers.

Francis, D. and Bessant, J. (2005). Targeting Innovation and Implications for Capability Development. Technovation 25(3), 171-183.

Graff, O. (2014). Yoik - The Traditional Folk Music of the Sámi People. In M.A. Hauan (Ed.), Sámi Stories: Art and Identity of an Arctic People (pp. 67-78). Tromsø: Orkana Akademisk.

Graham, M. and Hogan, B. (2014). Uneven Openness: Barriers to MENA Representation on Wikipedia. Report. Oxford Internet Institute: University of Oxford, UK. Retrieved from http://papers.ssrn.com/ sol3/papers.cfm?abstract id=2430912
Helander, N.O. (2005). Lese og Skriveopplæring på Samisk. In G. Alhaug, E. Mørck and A.K. Pedersen (Eds.), Mot rikare mål å trå: Festskrift til Tove Bull (pp. 107-117). Oslo: Novus Forlag.

Hourigan, N. (2004). Escaping the Global Village: Media, Language and Protest. Oxford: Lexington Books.

Ijäs, A. (2012). Samer i to norske nyhetsmedier: En undersøkelse av saker med samisk hovedfokus i Nordlys og Dagsrevyen i perioden 1970-20oo. Kautokeino: Sámi University College.

Internet Archive. (2014). Wayback Machine. Retrieved from https://archive.org/web

Jones, E. H. G. (2013). Minority Language Media, Convergence Culture and the Indices of Linguistic Vitality. In E. H. G. Jones and E. Uribe-Jongbloed (Eds.), Social Media and Minority Languages: Convergence and the Creative Industries (pp. 58-74). Bristol: Multilingual Matters.

Jones, E. H. G. and Uribe-Jongbloed, E. (2013). (Eds.), Social Media and Minority Languages: Convergence and the Creative Industries. Bristol: Multilingual Matters. 
Kelly-Holmes, H. (2014). Commentary: Mediatized spaces for minoritized languages. Challenges and Opportunities. In Jannis Androutsopoulos (Ed.), Mediatization and Sociolinguistic Change (pp. 539544). Berlin: DeGruyter.

Latour, B. (2005). Reassembling the Social: An Introduction to Actor-Network-Theory. Oxford: Oxford University Press.

Lie, M. and Sørensen, K. H. (1996). Making Technology our Own? Domesticating Technology into Everyday Life. Scandinavian University Press.

Lievrouw, L. A. (2012). Preface: The Internet, as Though Agency Matters. In A. Feenberg and N. Friesen (Eds.) (Re)Inventing the Internet: Critical Case Studies (pp. vii - x). Rotterdam: Sense Publishers.

Lievrouw, L. A. and Livingstone, S. (2006). Introduction to the updated student edition. In L. A. Lievrouw and S. Livingstone (Eds.), The handbook of new media (updated student edition) (pp. 1-14). London: Sage.

Magga, O. H. (1997). Samisk språk. In A. Karker, B. Lindgren and S. Løland (Eds.), Nordens språk (pp. 137-160). Oslo: Novus.

Magga, O.H. (2014). Policy and the Sámi Language. In M.A. Hauan (Ed.), Sámi Stories: Art and Identity of an Arctic People (pp. 9-22). Tromsø: Orkana Akademisk.
Magga, T. (2002). North Saami and majority languages. In E. Mørck and T. Magga (Eds.), Samiska i ett nytt årtusende (pp. 117-134). Köpenhamn: Nordiska ministerrrådet.

Malcolm, I. (1997). Living with Irish. In A. Mac Póilín (Ed.), The Irish Language in Northern Ireland (pp. 7-30). Belfast: Ultach Trust.

Mansell, R. (1996). Communication by Design? In R. Mansell and R. Silverstone (Eds.), Communication by design: the politics of information and communication technologies (pp. 15-43). Oxford: Oxford University Press.

Marwick, A. E. and boyd, d. (2011). I Tweet Honestly, I Tweet Passionately: Twitter Users, Context Collapse, and the Imagined Audience. New Media and Society, 13(1), 96-113.

Moore, R. E., Pietikäinen, S., and Blommaert, J. (2010). Counting the Losses: Numbers as the Language of Endangerment. Sociolinguistic Studies, 4(1), 1-26.

Moriarty, M. (2014). Súil Eile: Media, sociolinguistic change and the Irish language. In J. Androutsopoulos (Ed.), Mediatization and Sociolinguistic Change (pp. 463-486). Berlin: De Gruyter.

Moulaert, F., MacCallum, D., Mehmood, A. and Hamdouch, A. (2013). (Eds.). The International Handbook on Social Innovation: Collective Action, Social Learning and Transdisciplinary Research. Cheltenham: Edward Elgar Publishing Limited.
Mulgan, G. (2012). Social Innovation Theories: Can Theory Catch Up with Practice? In H.W. Franz, J. Hochgerner, J. Howaldt. (Eds.), Challenge Social Innovation (pp. 19-42). Berlin Heidelberg: SpringerVerlag. DOI: 10.1007/978-3-642-32879-4_2.

McMonagle, S. (2012). Finding the Irish Language in Canada. New Hibernia Review, 16(1), 134-149. Retrieved from http://mwbdvjh.muse.jhu.edu/journals/new hibernia review/vo16/16.1.mcmonagle pdf.

Ní Bhroin, N. (2015, in preparation). Lost in Space? Reaching-out to use Minority Languages in Social Media. Unpublished Paper.

Ní Bhroin, N. (2013). Small Pieces in a Social Innovation Puzzle? Exploring the Motivations of Minority Language Users in Social Media. In Storsul, T. and Krumsvik, A.H. (Eds.), Media Innovations: A Multidisciplinary Study of Change (pp. 219-238). Göteborg: Nordicom.

Ó Giollagáin, C., Mac Donnacha, S., Ní Chualaín, F., Ní Shéaghdha, A., O’Brien, M. (2007). Comprehensive Linguistic Study of the Use of Irish in the Gaeltacht. Dublin: The Department of Community, Rural and Gaeltacht Affairs. Retrieved from http://www.ahg. gov.ie/ie/Straiteis20BliaindonGhaeilge2010-2030/ Foilseachain/Staidéar\%20Cuimsitheach\%20 Teangeola\%C3\%ADoch\%20ar\%20Úsáid\%20na\%20 Gaeilge\%20sa\%20Ghaeltacht\%20(achoimre).pdf 
Ó hIfearnáin, T. (2001). Irish Language Broadcast Media: The Interaction of State Language Policy, Broadcasters and their Audiences. In H. KellyHolmes (Ed). Minority Language Broadcasting: Breton and Irish, (pp. 6-30). Clevedon: Multilingual Matters.

Oudshoorn, N. and Pinch, T. (Eds.), (2003). How Users Matter: The Co-Construction of Users and Technology. Cambridge, MA: The MIT Press.

Pietikäinen, S. and Kelly-Holmes, H. (2011). Gifting, service and performance: three eras in minoritylanguage media policy and practice. International Journal of Applied Linguistics, 21(1), 51-70.

Rasmussen, T. and Nolan, S. (2011). Reclaiming Sámi languages: indigenous language emancipation from East to West. International Journal of the Sociology of Language (209), 35-55.

Sametinget. (2012). Sametingsmelding om Samisk Språk. Retrieved from http://www.sametinget.no/ Spraak/Sametingsmelding-om-samisk-spraak

Scannell, K. (2007). The Crúbadán Project: Corpus building for under-resourced languages. Cahiers $d u$ Cental, 5, 1-10.
Scannell, K. (2013). Indigenous Tweets, Visible Voices, and Technology. Panel Discussion at South-bySouthwest. March 2013. Austin: Texas.

Scannell, K. (2014a). Indigenous Tweets. Retrieved from www.indigenoustweets.com

Scannell, K. (2014b). Crubadan. Retrieved from http:// borel.slu.ed/crubadan.

Scannell, K. (2014c). Geolocation of Northern Sámi Tweets. Retrieved from https://github.com/kscanne/itweets-geodata/blob/master/mentions/ se.geojson

Scannell, K. (2014d). Mapping the Celtic Twittersphere. Retrieved from http://indigenoustweets.blogspot. no.

Shtern, J., Paré, D. J., Ross, P. and Dick, M. (2013). Historiographic Innovation. How the Past Explains the Future of Social Media Services. In Storsul, T. and Krumsvik, A. H. (Eds.), Media Innovations: A Multidisciplinary Study of Change (pp. 239-254). Göteborg: Nordicom.

Silverstone, R. and Hirsch, E. (Eds.). (1992). Consuming Technologies: Media and Information in Domestic Spaces. London: Routledge
Skogerbø, E. (2000). Konflikt eller kuriosa? Om representasjon av den samiske minoriteten i majoritetsmedier i Norge. Nordicom Information, 22(34), 65- 75 .

Storsul, T. and Krumsvik, A. H. (Eds). (2013). Media Innovations: A Multidisciplinary Study of Change. Göteborg: Nordicom.

Sørensen, K. H. (2013). Beyond Innovation: Towards an extended framework for analysing technology policy. Nordic Journal of Science and Technology Studies, 1(1), 12-23.

Twitter. (2014). Retrieved from www.twitter.com von Hippel, E. (2005). Democratizing Innovation. Cambridge, Mass.: The MIT Press.

Watson, I. (2003). Broadcasting in Irish: Minority Language, radio, television and identity. Dublin Four Courts Press.

Weber, J.-J. and Horner, K. (2012). Introducing Multilingualism: A Social Approach. Abingdon,New York: Routledge.

Westlund, O. and Lewis, S. C. (2014). Agents of Media Innovations: Actors, Actants and Audiences. The Journal of Media Innovations, 1(2), 10-35 